\title{
Characterization and Identification of Allergen Protein in Shrimp Before and After Heated with SDS-PAGE Method
}

Emma Emawati*
Idar
Resta Ramadiyanti
Department of Pharmacy, Sekolah
Tinggi Farmasi Bandung, Bandung,
West Java, Indonesia
*email: emma.emawati@stfb.ac.id
Keywords:
Allergen protein
Ion Exchange Chromatography
SDS-PAGE
Shrimp

\begin{abstract}
Food allergies are one of the most common allergies in Indonesian society. Generally, when children aged 5-6 years food allergies will disappear, except peanut allergies and allergies to seafood, such as fish, shellfish and crustaceans. This study aims to determine the pattern of separation of allergen proteins in shrimp using anion exchange column chromatography method and identify allergen proteins in shrimp using the sodium dodecyl sulfate-polyacrylamide gel electrophoresis (SDS-PAGE) method. Protein extraction from shrimp using Phosphate buffer saline (PBS) pH 7.2 and centrifuged at $10,000 \mathrm{rpm}$ for $10 \mathrm{~min}$ at $4^{\circ} \mathrm{C}$. Protein separation was carried out by anion-exchange column chromatography method, and the fraction obtained was measured at $280 \mathrm{~nm}$ wavelength. The highest yield at absorbance was identified by using SDS-PAGE. Polyacrylamide gel electrophoresis was used to determine the protein profile and molecular weight of shrimp extract. Coloring of protein bands using silver staining. Data were analyzed descriptively based on the migration value of the sample protein bands compared to the marker protein band (Rf). The results of protein allergen profile analysis on shrimp using SDS-PAGE showed that the shrimp contained a protein band with a molecular weight of $37.77 \mathrm{kDa}$ for cooked shrimp and $37.03 \mathrm{kDa}$ for fresh shrimp.
\end{abstract}

Received: August $10^{\text {th }} 2019$

Accepted: October 22nd 2019

Published: November 14th 2019

(c) 2019 Emma Emawati, Idar, Resta Ramadiyanti. Published by Institute for Research and Community Services Universitas Muhammadiyah Palangkaraya. This is an Open Access article under the CC-BY-SA License (http://creativecommons.org/licenses/by-sa/4.0/). DOI: https://doi.org/10.33084/bjop.v2i2.901.

\section{INTRODUCTION}

Allergic reactions or hypersensitivity are reactions of the immune system that occur when healthy body tissue is injured. Food allergies become a bother for someone who is allergic. Allergies are triggered by the consumption of allergen sources, mainly in the form of protein (Ellenbogen et al., 2018). Food allergies that are very common among Asians are allergies caused by seafood. Seafood that can cause allergies is usually included in the group of Crustaceans (Tong et al., 2018).

Crustaceans are recognized as a cause of food allergic reactions. Allergic reactions from seafood can occur, starting from processing to being ready to be served. (Lopata et al., 2016). One of the most commonly consumed crustaceans and the most crucial contribution to allergies is shrimp. The value of protein in shrimp is categorized as a complete protein because of high amino acid levels, complete profile and about $85-95 \%$ are easy to digest. Protein content in shrimp is a major cause of allergies. This protein component can cause allergic reactions, especially in the respiratory system (Thalayasingam et al., 2015).

There are three types of protein allergens in shrimp, each of which has a molecular weight of $38 \mathrm{kDa}, 36 \mathrm{kDa}$ and 34 kDa (Musmand et al., 1993). Gomaa and Boye (2015) measured allergen protein levels using a comparison of the enzyme-linked immunosorbent assay (ELISA), liquid chromatography-mass spectrometry (LC-MS), and rapid 
test methods. Another method that can be used for protein identification is sodium dodecyl sulfatepolyacrylamide gel electrophoresis (SDS-PAGE). This method is more economical than ELISA and LC-MS. The SDS-PAGE is one of the electrophoresis development methods, where the method is a separation technique that separates the analyte based on its ability to move in a conduction medium which is usually in the form of a buffer solution and will respond after an electric field is added. Various types of proteins in a sample will be separated separately in polyacrylamide gels depending on their mobility, thus in the path of protein movement will get a range of proteins called protein bands that will separate based on the size of the molecular weights of proteins (Rabilloud et al., 2009).

The final results of the study indicate that the heating process can reduce allergen protein levels. The heating process is known almost always done in seafood processing, including shrimp. Thus, it is suspected that shrimp that go through a heating process will have lower levels of allergen protein than before heating. This study aims to obtain a comparison of the characteristics and identity of protein allergens that appear in shrimp that have not been processed or heated. The method used for allergen protein classification is SDS-PAGE, while for the separation of allergen proteins it uses Ion Exchange Chromatography.

\section{MATERIALS AND METHODS}

Shrimp samples used were $150 \mathrm{~g}$ of fresh shrimp and 150 g of cooked shrimp (by boiled) obtained from the Subang Fish Market, West Java. The extraction process is done by crushing and homogenizing the shrimp using a blender with phosphate-buffered saline (PBS) pH 7.2 until homogeneous. Homogenization results in a centrifuge for ten minutes at $4^{\circ} \mathrm{C}$ at $10,000 \mathrm{rpm}$.
Separation of allergen protein from crude extracts that have been obtained is done by homogenization by ionexchange chromatography. The stationary phase used was Sephadex DEAE-25 anion exchange and the mobile phase used was PBS pH 7.2 and salt gradient. The fraction that is stored every $2 \mathrm{ml}$ is then measured for absorbance at the wavelength $(\lambda)$ of $280 \mathrm{~nm}$.

Sample preparation was carried out before the SDSPAGE process. Preparation is done by mixing the sample solution with PBS (15 $\mu \mathrm{l}$ sample : $5 \mu \mathrm{l}$ PBS), then incubated at $37^{\circ} \mathrm{C}$ for 15 minutes. The SDS PAGE classification consists of two parts, 16\% resolving gel and $4 \%$ gel stacking. The composition of resolving gel and gel stacking is presented in Table I.

Table I. Composition of resolving gel and gel stacking in SDS-PAGE

\begin{tabular}{lcc}
\hline \multicolumn{1}{c}{ Composition } & Resolving gel & Stacking gel \\
\hline Distilled water $(\mathrm{ml})$ & 5 & 5 \\
AB-3 $(\mathrm{ml})$ & 3.33 & 0.4164 \\
Buffer Gel $(\mathrm{ml})$ & 3.33 & 1.26 \\
Glycerol $(\mathrm{ml})$ & 1 & - \\
APS $10 \%(\mu \mathrm{l})$ & 45 & 45 \\
TEMED $(\mu \mathrm{l})$ & 6 & 6 \\
\hline
\end{tabular}

Electrophoresis is carried out by placing prepared sample solutions and markers into the SDS-PAGE well. Electrophoresis was carried out for approximately two hours with a voltage of 30 volts until the gel stacking solution was then carried out running with a voltage of 100 volts until the gel began to fall.

Silver staining is done by soaking the gel in a solution of $50 \%$ fixation of acetic acid overnight with a gentle shake. After fixation is complete, the gel is rinsed with distilled water for ten minutes, then washed with $20 \%$ ethanol solution. The gel was then rinsed with distilled water for ten minutes, then sensitized using $\mathrm{Na}_{2} \mathrm{~S}_{2} \mathrm{O}_{3}$ for one minute. The gel is again rinsed with distilled water three times with 20 minutes each. Then the gel was stained with $0.1 \%$ silver nitrate for 20 minutes and stored at $4^{\circ} \mathrm{C}$. The gel is rinsed again with distilled water two times each for 20 minutes. The gel was then soaked in a developer 
solution consisting of $5 \% \mathrm{Na}_{2} \mathrm{CO}_{3}+0.05 \%$ formaldehyde $+0.0004 \% \mathrm{Na}_{2} \mathrm{~S}_{2} \mathrm{O}_{3}$ until it was sufficient, the soaked gel was given a stop solution containing $6 \mathrm{ml}$ of acetic acid and $440 \mathrm{~m}$; of distilled water for five minutes. Finally, the gel is then washed with distilled water for five minutes.

\section{RESULTS AND DISCUSSION}

Shrimp samples that have been selected are then carried out the process of protein extraction in shrimp using PBS $\mathrm{pH} 7.2$ then centrifuged at a speed of $10,000 \mathrm{rpm}$ at $4{ }^{\circ} \mathrm{C}$ for ten minutes. The main problem in terms of protein extraction is that it can remove protein from cells without being degraded or denatured and is not contaminated so that it can be overcome by choosing the right extract medium, fast preparation time and at low-temperature conditions (Tan \& Yiap, 2009). Centrifugation is used to separate proteins based on molecular weight. Extraction is carried out using PBS $\mathrm{pH} 7.2$ because the ideal extraction buffer for the target protein is usually between pH 7.0 and 8.5, which aims to help stabilize the protein target or block it from unwanted protein activity (Bonner, 2018). From the results of the extraction of $150 \mathrm{~g}$ of fresh shrimp obtained liquid extracts of about $5 \mathrm{ml}$, while the results of the extraction of cooked shrimp as much as 150 g also obtained liquid extracts of $5 \mathrm{ml}$.

Supernatants resulting from extraction are further separated by ion-exchange chromatography which aims to separate proteins based on the working principle of reversible electrostatic attraction from charged molecules with a matrix containing covalently charged and bonded opponents. Separation of allergen protein by ionexchange chromatography method using the stationary phase Sephadex DEAE A-25 and the mobile phase PBS pH 7.2 and also NaCl 1 M in PBS pH 7.2. Separation of allergen protein using ion-exchange chromatography method is done based on isoelectric point, where the isoelectric point of shrimp allergen protein is around 5.6.
For this reason, an elution solvent in the form of PBS $\mathrm{pH}$ 7.2 is used to make the negatively charged target protein (allergen protein) bound to the stationary phase. To release the target protein that has been bound to the stationary phase, and elution of increasing the salt gradient is carried out until it reaches $1 \mathrm{M} \mathrm{NaCl}$ concentration in PBS pH 7.2.

The absorbance measurements were made at $\lambda$ of $280 \mathrm{~nm}$ to determine the protein in a particular fraction. From the results of these measurements obtained a protein profile in the form of a fraction of \pm 140 separate tubes in fractions-based on the ion charge for each sample. The results of purification by anion exchange chromatography show that not all fractions have activity, only a few fractions that have activity seen in the absorbance measurement results at $\lambda$ of $280 \mathrm{~nm}$ are presented in Figure 1 and Figure 2, respectively. Based on the results of the fractions that have been obtained, there are around the three highest fraction peaks, where the peak of the highest fraction of the first and the second is suspected impurity because it descends first without being bound to the stationary phase. In contrast, the third-highest fraction peak was suspected to be allergen protein in shrimp because it fell on the elution of $1 \mathrm{M}$ $\mathrm{NaCl}$ in PBS pH 7.2, which was subsequently collected and classified using SDS-PAGE.

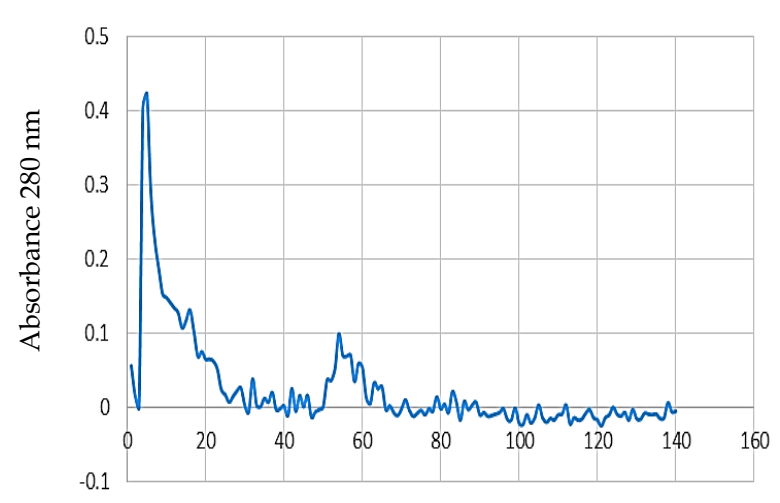

Figure 1. The results of purifying fresh shrimp protein using ion-exchange chromatography 


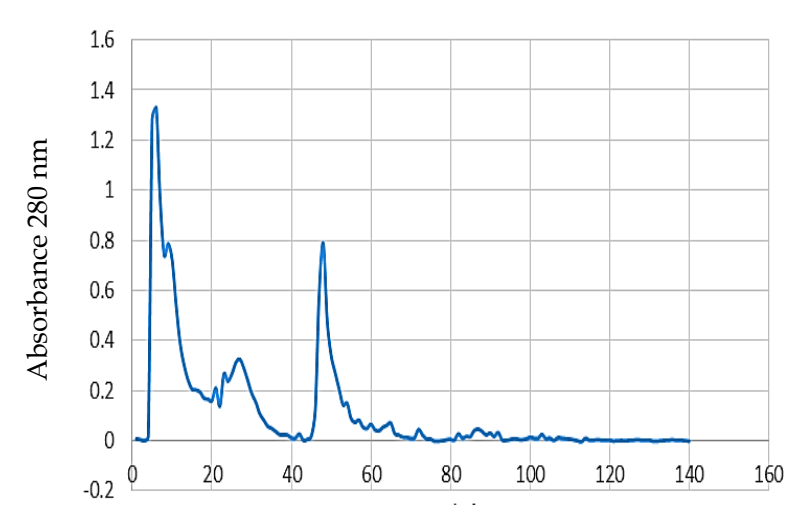

Figure 2. The results of purifying cooked shrimp protein using ion-exchange chromatography

Furthermore, after a purified protein profile was found with anion exchange chromatography, then the fraction peaks were collected and identified by SDS-PAGE. Analysis of allergen protein in shrimp was done by SDSPAGE using polyacrylamide gel as a separation medium. The results of the identification of allergen proteins in fresh and cooked shrimp are presented in Figure 3 and Figure 4, respectively.

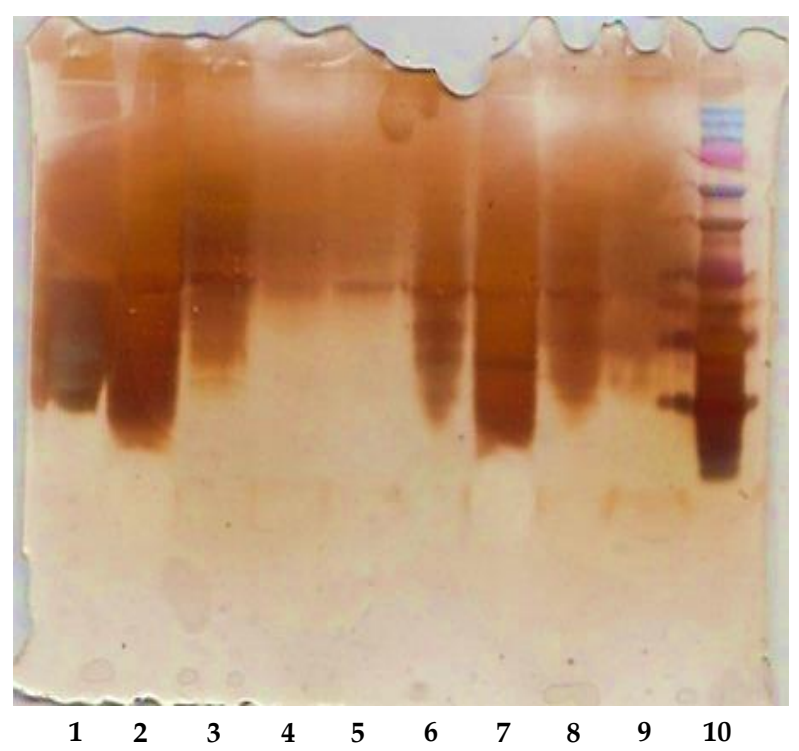

Figure 3. Results of SDS-PAGE electrogram Tricine samples of fresh shrimp, silver staining dye. Crude extract (1); chromatography results of fraction anion exchangers $4,5,6,7$, 8,9 and 10 (2); fractions 13,14,15,16 and 17 (3); fractions 53, 54, 55,56 , and 57 (4); fractions 63, 64, and 65 (5); fraction 32 (6); fraction 5 (7); fraction 17 (8); fraction 54 (9); protein standard (10). Standard molecular weight measurements from top to bottom are 250, 150, 100, 75, 50, 37, 25, 20, 15, and $10 \mathrm{kDa}$, respectively.

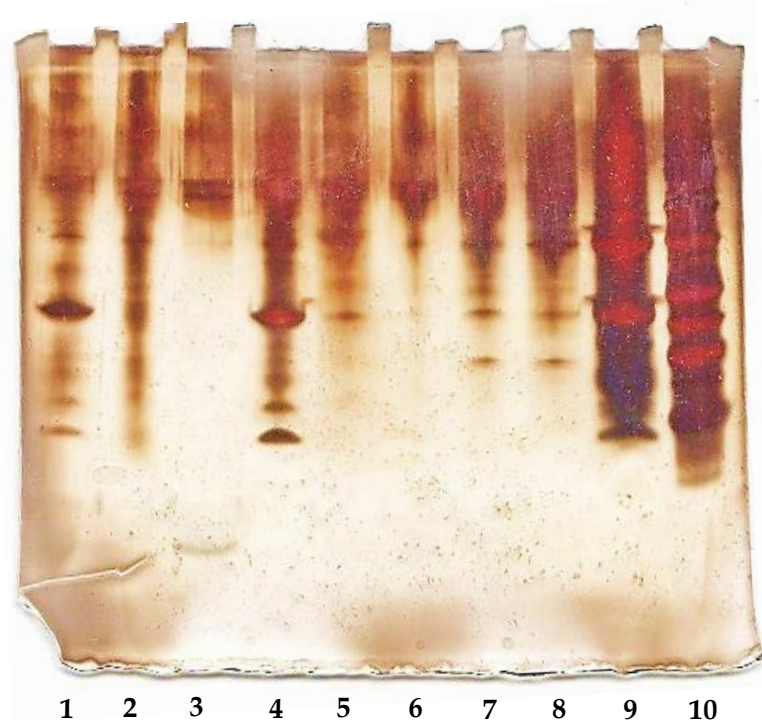

Figure 4. Results of SDS-PAGE electrogram Tricine samples of cooked shrimp, silver staining dye. Chromatography results of fraction anion exchangers 5, 6, 7, 8, 9 and 10 (1); fractions 26, 27 and 28 (2); fractions 47, 48, 49 and 50 (3); fraction 6 (4); fraction 27 (5); fraction 27 (6); fraction 27 (7); fraction 47 (8); crude cooked shrimp extract (9); protein standard (10). Standard molecular weight measurements from top to bottom are 250,

$150,100,75,50,37,25,20,15$, and $10 \mathrm{kDa}$, respectively.

The use of polyacrylamide has advantages compared to other gels because it does not react with the sample and does not form a matrix with the sample. Therefore, it does not slow down the movement of the sample, which allows complete separation of proteins, besides that the polyacrylamide gel has a high enough separation power (Rudge \& Monnig, 2000). The use of SDS functions to denaturate proteins because it is a detergent which results in the bonding of the protein being broken off to form proteins that can be eluted in the gel as well as mercaptoethanol.

In this system, the gel used consists of two different types of gel, namely running gel and stacking gel. Separation of proteins by polyacrylamide gel electrophoresis is based on differences in charge and molecular size. Essential components that make up the polyacrylamide gel are acrylamide, bis acrylamide, ammonium persulfate and tetramethylethylenediamine (TEMED) (Nowakowski et al., 2014). Acrylamide is the main compound that makes up the gel because it is a carcinogenic compound. 
Ammonium persulfate functions as the initiator that activates acrylamide to react with other acrylamide molecules to form long polymer chains. The TEMED acts as a catalyst for the polymerization of acrylamide into polyacrylamide gels so that it can be used in protein separation. Bis-acrylamide functions as a cross-linking agent that forms a lattice with an acrylamide polymer. The lattice functions as a protein molecule sieve. The ratio between acrylamide and bis-acrylamide can be adjusted according to the molecular weight of the protein to be separated. The lower molecular weight of the separated protein, the higher concentration of acrylamide is used so that the grating formed is denser (Rath et al., 2013).

In the sample preparation process, the sample buffer is added to the sample containing Tris-HCl, SDS, glycerol, bromophenol blue and mercaptoethanol. The purpose of using SDS and mercaptoethanol with heating will break down the three-dimensional structure of proteins, especially disulfide bonds into individual polypeptide subunits. The SDS also encloses a protein chain that is bound to the same negative charge to form an SDSprotein complex. The SDS-protein complex has an identical charge density and moves on the gel-based only on the size of the protein. Therefore, larger SDS-protein complexes have lower mobility compared to smaller SDS-protein complexes (Hafiz, 2004).

In this study, the electrophoresis was regulated with a voltage of 30 volts to reach the limit of stacking gel with a current of $400 \mathrm{~mA}$, and then after reaching the limit of stacking gel, the voltage was increased to 100 volts with $400 \mathrm{~mA}$ for 80 minutes. This process is done to equalize the sample to begin. Electrophoresis was carried out with samples of shrimp allergen protein purification results using ion-exchange chromatography and using a standard molecular weight comparator (marker protein) Bio-Rad Precision Plus Protein ${ }^{\mathrm{TM}}$ Dual Color Standards. From the electrophoresis obtained the migration distance from standard proteins, which is then compared with the migration distance of the blue bromophenol dye, the Rf value is obtained. The $\mathrm{Rf}$ or retention factor is the inhibitory factor of protein separation in the gel using the principle of inhibition of the migration rate of these proteins so that separation due to differences in molecular weight results in the formation of bands at different migration distances from each other and the distance is converted to Rf values (Oh-Ishi \& Maeda, 2002; Rosenberg, 1996).

From the SDS-PAGE analysis using silver staining, protein molecules contained in the extract of shrimp protein resulting from ion-exchange chromatography separation obtained linear regression model, namely for fresh shrimp, the linear regression model $y=-2.0519 x+$ 2.2952; $\mathrm{R}=0.9426 ; \mathrm{r}=0.9708$ while in cooked shrimp $\mathrm{y}=$ $-2.2027 x+2.7032 ; \quad \mathrm{R}=0.9736 ; \mathrm{r}=0.9867$. The polyacrylamide gel produced the same band for all fresh shrimp produced the same band to obtain a molecular weight of $37.03 \mathrm{kDa}$ which was calculated by extrapolating the linear regression equation in Figure 5, while the migration distance from the marker along with the Rf value and molecular weight of each cooked shrimp sample bands are presented in Table II. While in cooked shrimp the molecular weight is $37.77 \mathrm{kDa}$ by extrapolating the regression, equation obtained from a standard protein whose molecular weight is known as shown in Figure 6, while the migration distance from the marker and Rf values and molecular weights of each band of cooked shrimp are presented in Table III.

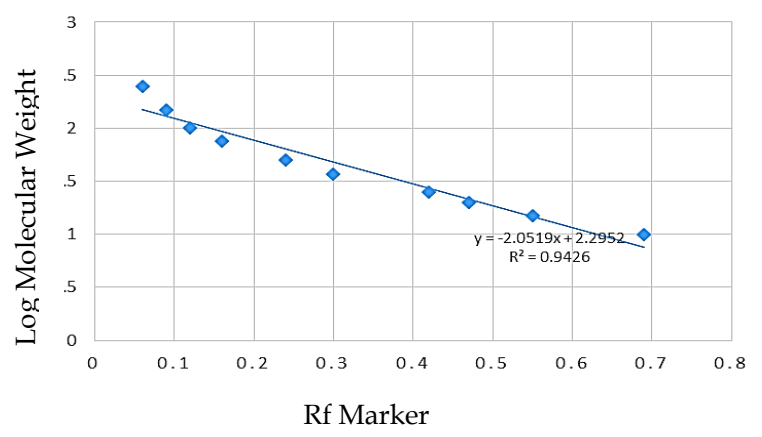

Figure 5. Fresh shrimp marker curve 
Table II. The migration distance from the marker along with the Rf value and molecular weight of each fresh shrimp sample band

\begin{tabular}{cccc}
\hline $\begin{array}{c}\text { Marker } \\
\text { distance } \\
\text { (cm) }\end{array}$ & Rf Marker & $\begin{array}{c}\text { Molecular } \\
\text { weight } \\
\text { marker }\end{array}$ & $\begin{array}{c}\text { Log } \\
\text { Molecular } \\
\text { weight }\end{array}$ \\
\hline 0.6 & 0.06 & 250 & 2.39794 \\
0.9 & 0.09 & 150 & 2.176091 \\
1.2 & 0.12 & 100 & 2 \\
1.6 & 0.16 & 75 & 1.875061 \\
2.4 & 0.24 & 50 & 1.69897 \\
3 & 0.3 & 37 & 1.568202 \\
4.2 & 0.42 & 25 & 1.39794 \\
4.7 & 0.47 & 20 & 1.30103 \\
5.5 & 0.55 & 15 & 1.176091 \\
6.9 & 0.69 & 10 & 1 \\
\hline
\end{tabular}

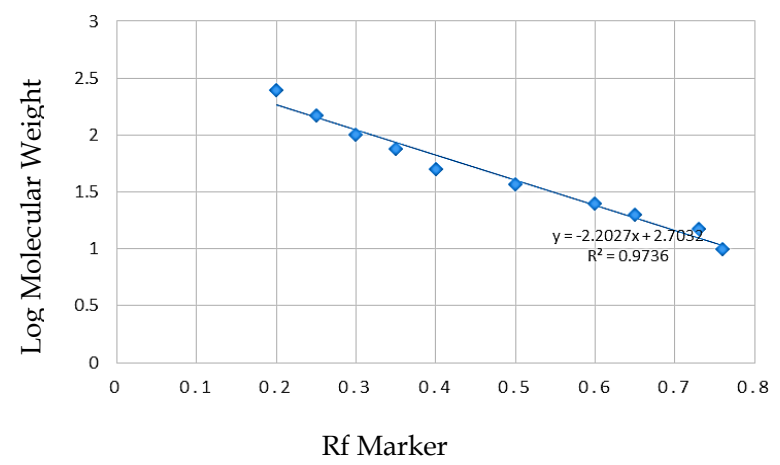

Figure 6. Cooked shrimp marker curve

Table III. The migration distance from the marker along with the Rf value and molecular weight of each cooked shrimp sample band

\begin{tabular}{cccc}
\hline $\begin{array}{c}\text { Marker } \\
\text { distance } \\
\text { (cm) }\end{array}$ & Rf Marker & $\begin{array}{c}\text { Molecular } \\
\text { weight } \\
\text { marker }\end{array}$ & $\begin{array}{c}\text { Log } \\
\text { Molecular } \\
\text { weight }\end{array}$ \\
\hline 2 & 0.2 & 250 & 2.39794 \\
2.5 & 0.25 & 150 & 2.176091 \\
3 & 0.3 & 100 & 2 \\
3.5 & 0.35 & 75 & 1.875061 \\
4 & 0.4 & 50 & 1.69897 \\
5 & 0.5 & 37 & 1.568202 \\
6 & 0.6 & 25 & 1.39794 \\
6.5 & 0.65 & 20 & 1.30103 \\
7.3 & 0.73 & 15 & 1.176091 \\
7.6 & 0.76 & 10 & 1 \\
\hline
\end{tabular}

\section{CONCLUSION}

From the results, it can be concluded that the allergen protein in shrimp before and after heating can be separated using ion-exchange chromatography method with a Sephadex DEAE A-25 matrix, based on its isoelectric point so that a fraction of 140 fractions per sample is obtained and the results of the allergen protein at 54 for fresh shrimp and fraction number 47 for cooked shrimp. However, the level of purity obtained did not reach $100 \%$, which was subsequently identified by SDSPAGE to obtain a molecular weight value for fresh shrimp $37.07 \mathrm{kDa}$ and cooked shrimp $37.77 \mathrm{kDa}$. The results of this study can be continued to identify the type and structure of the allergen protein that has been successfully isolated from both fresh and cooked shrimp.

\section{ACKNOWLEDGMENT}

This work was supported by a grant from Direktorat Riset dan Pengabdian Masyarakat Kementerian Riset Teknologi dan Pendidikan Tinggi Republik Indonesia (Directorate of Research and Community Service Ministry of Research Technology and Higher Education Republic of Indonesia) through the scheme Penelitian Dosen Pemula.

\section{REFERENCES}

Bonner, P. 2018. Protein Purification. 2nd Edition. Boca Raton: CRC Press, Taylor \& Francis.

Ellenbogen, Y., Jimenez-Saiz, R., Spill, P., Chu, D.K., Waserman, S., Jordana, M. 2018. The Initiation of Th2 Immunity Towards Food Allergens. International Journal of Molecular Sciences. 19(5):1447. https://dx.doi.org/10.3390/ijms19051447

Gomaa, A., Boye, J. 2015. Simultaneous detection of multi-allergens in an incurred food matrix using ELISA, multiplex flow cytometry and liquid chromatography mass spectrometry (LC-MS). Food Chemistry. 175:585-592. https://doi.org/10.1016/j.foodchem.2014.12. 017

Hafiz, A. 2004. Principles and Reactions of Protein Extraction, Purification, and Characterization. Boca Raton: CRC Press, Taylor \& Francis. https://doi.org/10.1201/9780203507438

Lopata, A.L., Kleine-Tebbe, J., Kamath, S.D. 2016. Allergens and molecular diagnostics of shellfish allergy: Part 22 of the Series Molecular Allergology. Allergo Journal International. 25(7):210-218. 
https://dx.doi.org/10.1007/s40629-016-0124 2

Musmand, J.J., Dul, C.B., Lehrer, S.B. 1993. Crustacea Allergy. Clinical \& Experimental Allergy. 23(9):722-732. https://doi.org/10.1111/j.13652222.1993.tb00359.x

Nowakowski, A.B., Wobig, W.J., Petering, D.H. 2014. Native SDS-PAGE: High Resolution Electrophoretic Separation of Proteins with Retention of Native Properties Including Bound Metal Ions. Metallomics. 6(5):1068-1078. https://dx.doi.org/10.1039/c4mt00033a

Oh-Ishi, M., Maeda, T. 2002. Separation techniques for high-molecular-mass proteins. Journal of Chromatography B: Analytical Technologies in the Biomedical and Life Sciences. 771(1-2):49-66. https://doi.org/10.1016/S15700232(02)00112-5

Rabilloud, T., Vaezzadeh, A.R., Potier, N., Lelong, C., Leize-Wagner, E., Chevallet, M. 2009. Power and limitations of electrophoretic separations in proteomics strategies. Mass Spectrometry Reviews. 28(5):816-843. https://doi.org/10.1002/mas.20204

Rath, A., Cunningham, F., Deber, C.M. 2013. Acrylamide concentration determines the direction and magnitude of helical membrane protein gel shifts. Proceedings of the National Academy of Sciences of the United States of America. 110(39):15668-15673.

https://dx.doi.org/10.1073/pnas.1311305110

Rosenberg, I.M. 1996. Protein Analysis and Purification. Boston: Birkhäuser, Springer. https://doi.org/10.1007/978-1-4612-2056-5

Rudge, S.R., Monnig, C.A. 2000. Electrophoresis Techniques. Separation and Purification Methods. 29(1):129-148. https://doi.org/10.1081/SPM100100006

Tan, S.C., Yiap, B.C. 2009. DNA, RNA, and Protein Extraction: The Past and The Present. Journal of Biomedicine and Biotechnology. 2009:574398. https://dx.doi.org/10.1155/2009/574398

Thalayasingam, M., Gerez, I.F., Yap, G.C., Llanora, G.V., Chia, I.P., Chua, L., Lee, C.J., Ta, L.D., Cheng, Y.K., Thong, B.Y., Tang, C.Y., Yan Bever, H.P., Shek, L.P., Curotto de Lafaille, M.A., Lee, B.W. 2015. Clinical and immunochemical profiles of food challenge proven or anaphylactic shrimp allergy in tropical Singapore. Clinical \& Experimental Allergy. 45(3):687-697. https://doi.org/10.1111/cea.12416

Tong, W.S., Yuen, A.W.T., Wai, C.Y.Y., Leung, N.Y.H., Chu, K.H., Leung, P.S.C. 2018. Diagnosis of fish and shellfish allergies. Journal of Asthma and Allergy. 11:247-260. https://dx.doi.org/10.2147/JAA.S142476 